\title{
Predicting tree pollen season start dates using thermal conditions
}

\author{
Dorota Myszkowska
}

Received: 31 August 2013/Accepted: 7 February 2014/Published online: 20 February 2014

(C) The Author(s) 2014. This article is published with open access at Springerlink.com

\begin{abstract}
Thermal conditions at the beginning of the year determine the timing of pollen seasons of early flowering trees. The aims of this study were to quantify the relationship between the tree pollen season start dates and the thermal conditions just before the beginning of the season and to construct models predicting the start of the pollen season in a given year. The study was performed in Krakow (Southern Poland); the pollen data of Alnus, Corylus and Betula were obtained in 1991-2012 using a volumetric method. The relationship between the tree pollen season start, calculated by the cumulated pollen grain sum method, and a 5-day running means of maximum (for Alnus and Corylus) and mean (for Betula) daily temperature was found and used in the logistic regression models. The estimation of model parameters indicated their statistically significance for all studied taxa; the odds ratio was higher in models for Betula, comparing to Alnus and Corylus. The proposed model makes the accuracy of prediction in $83.58 \%$ of cases for Alnus, in $84.29 \%$ of cases for Corylus and in $90.41 \%$ of cases for Betula. In years of model verification (2011 and 2012), the season start of Alnus and Corylus was predicted more precisely in 2011,
\end{abstract}

D. Myszkowska ( $₫)$

Department of Clinical and Environmental Allergology, Jagiellonian University Medical College, Śniadeckich 10, 31-531 Kraków, Poland e-mail: dmyszkow@cm-uj.krakow.pl; dorota.myszkowska@uj.edu.pl while in case of Betula, the model predictions achieved $100 \%$ of accuracy in both years. The correctness of prediction indicated that the data used for the model arrangement fitted the models well and stressed the high efficacy of model prediction estimated using the pollen data in 1991-2010.

Keywords Alnus $\cdot$ Corylus $\cdot$ Betula pollen seasons $\cdot$ Mean and maximum temperature fluctuations - Logistic regression - Predictive models

\section{Introduction}

Temperature is one of the major environmental factors that determines the readiness of plants to flower. In temperate climate, many species need a period of exposure to low, but not freezing temperature to acquire reproductive competence and an ability to flower (Dahl et al. 2013). For trees, especially those pollinating at the beginning of the year, thermal conditions and critical photoperiod following the time of the chilling control the start of flowering and leaf bud burst (Sofiev et al. 2009).

The different phenomena connected with the relationship between meteorological elements and plant behaviour, including the pollen occurrence in the atmosphere, are used to construct the mathematical models predicting the pollen season start. The observation-based models refer to the relationship between 
the pollen season start day and many meteorological elements, such as air temperature, rainfall, sunshine and snow cover occurring both before the pollen season and in the preceding season (Emberlin et al. 1993; Norris-Hill 1998; Corden et al. 2000; AdamsGroom et al. 2002; Rodriguez-Rajo et al. 2004). These models are constructed without knowledge of the sources, emission or calculations of diffusion (NorrisHill 1995). In contrast, process-based models refer to a given relationship between analysed variables. In this group of models, thermal-time models are most often used in phenological and aerobiological studies. These models work on the assumption that the speed of plant development depends on air temperature, which influences physiological processes like flower bud opening. Some papers on the thermal conditions required for the pollen season start dates of Corylus (Frenguelli et al. 1991; Frenguelli and Bricchi 1998), Alnus (Jato et al. 2000; Clot 2001; Rodriguez-Rajo et al. 2006; Emberlin et al. 2007) and Betula (Linkosalo et al. 2010) were published.

A review of threshold temperatures required by early-pollinating trees was presented by Dahl et al. (2013). Some controversies are related to the introduction of the time of absolute dormancy into the most sophisticated models. In temperate climates, the dormancy period of trees ends at the end of December or in January. Temperature, relative humidity and the number of days with sub-zero temperatures were reported as the main factors determining the start of Corylus pollen seasons in Sosnowiec (Silesia region, southern Poland) (Dąbrowska-Zapart 2008), while Piotrowska and Kaszewski (2009) pointed out the influence of accumulated 5-day running mean temperatures before the beginning of the Corylus pollen season in Lublin (eastern Poland). Phenological and aerobiological observations performed by Puc and Kasprzyk (2013) in Szczecin (Northwestern Poland) and Rzeszów (Southeastern Poland) indicated that hazel and alder trees flowered earlier in stands located in places exposed to sunlight and sheltered from the wind.

The previous analyses performed in Krakow showed that temperature during the last 10 days of February and relative humidity at the beginning of April were the best at explaining variations in Betula pollen season start dates and were included into multiple regression models as independent variables (Myszkowska 2013). In Alnus and Corylus pollen seasons, a strong negative correlation between the season start and mean temperature in January and mean temperatures during the 10 days just before the onset of the season was found by Myszkowska et al. (2006), while the paper by Piotrowicz and Myszkowska (2006) showed a statistically significant correlation between start dates of Corylus pollen seasons and the beginning of thermal early spring (temperature $>0{ }^{\circ} \mathrm{C}$ ).

Many aerobiological studies are focused on predicting the season start for medical purposes (Burr 1999; Chappard et al. 2004; Chuine and Belmonte 2004). In Poland, the early-pollinating trees, including Alnus, Corylus and (a bit later) Betula, are of great importance from a medical point of view. The analyses made by Burbach et al. (2009) showed that the clinically relevant sensitisation rate of Alnus, Corylus and Betula in Poland ranged from $59.6 \%$ (both for Alnus and Corylus) to $70.8 \%$ for Betula. The study conducted by Samoliński et al. (2009) in a group of 20,454 subjects in Poland indicated that the allergens of these tree taxa are responsible for allergic rhinitis symptoms generated in sensitive patients in spring in Poland. The construction of simple models based on thermal conditions has a practical application in allergology, e.g. to estimate the beginning of the allergen immunotherapy in patients sensitive to tree pollen allergens, especially in case of a preseasonal treatment.

The aims of this study were to examine the relationship between start dates of tree pollen seasons and thermal conditions just before the season and to construct models predicting the start of the pollen season in a given year.

\section{Materials and methods}

\subsection{Study site and climate}

The study was performed in Krakow $\left(50^{\circ} 3^{\prime} 41^{\prime \prime} \mathrm{N}\right.$, $19^{\circ} 56^{\prime} 18^{\prime \prime} \mathrm{E}$ ) (Southern Poland), one of the largest cities in Poland (Report on city conditions 2011) (http://www.bip.krakow.pl). To the north of Krakow, farmland with small forest communities occur. To the south and east, there are roughly equal areas of farmland and forests. To the west of the city, forest communities prevail. In Krakow, forests cover $4.38 \%$ of the total city area (1,431 ha). Krakow (and Poland 
in general) is influenced by air masses of polar-maritime origin coming from over the Northern Atlantic, which bring increased cloudiness, precipitation, warming and thaw in winter and increased cloudiness, rainfall and chilling in summer. The mean air temperature in Krakow in the twentieth century was $8.7^{\circ} \mathrm{C}$; 2000 was the hottest year $\left(11^{\circ} \mathrm{C}\right.$ ) (Piotrowicz 2007). The coldest month is January and the hottest July (with monthly temperature of -2.1 and $18.9^{\circ} \mathrm{C}$, respectively). Sunshine duration per day is $3.9 \mathrm{~h}$ although from April to September it is $5.7 \mathrm{~h}$ (Woś 1999). Annual precipitation is approximately $700 \mathrm{~mm}$. The highest rainfall level is recorded in summer (June, July and August). Annual humidity is $79 \%$, and winds from a westerly direction prevail. In Krakow, a heat island occurs with intensity in the city centre reaching $1.2{ }^{\circ} \mathrm{C}$ on average. The heat island is responsible for a change in the thermal season duration in the year. Summer in the city centre is longer by 25 days, and winter is shorter by 23 days than in suburban areas. Higher temperature in the city centre causes a longer vegetation season.

\subsection{Studied taxa}

All of the described taxa belong to the Betulaceae family (APGII 2003; APGIII 2009). Alnus glutinosa (L.) Gaertn., A. incana (L.) Moench and a shrub Alnus viridis (Chaix) DC. in Lam. \& DC. belonging to genus Alnus Miller occur in Poland. A. glutinosa is commonly found throughout the country, in wet forests, on the banks of streams, in river valleys and on lake shores, while $A$. incana is rather common in the southern part of Poland. A. viridis is found in the western part of the Bieszczady Mountains, from an altitude of $600 \mathrm{~m}$ a.s.l. up to summits (Seneta and Dolatowski 2007). In Poland, A. glutinosa usually starts flowering in the third decade of March or at the beginning of April, while the beginning of $A$. incana flowering is noted several days to three weeks earlier than A. glutinosa flowering. A. viridis starts flowering even at the end of May or at the beginning of June.

In Krakow, A. glutinosa is the most common Alnus species, especially in the southern part of the city and close to the city border in the north. Many A. glutinosa sites are observed in the vicinity of Krakow, particularly in the northwest part of the city and more commonly to the south of Krakow (Zając and Zając 2006).
The genus Corylus L. is commonly found throughout the whole of Poland. C. avellana L. occurs as a high shrub $(4 \mathrm{~m})$ or less often as a low tree. There are fewer Corylus sites within Krakow compared to outside of the city, the exception being the northeastern part of the Krakow (Zając and Zając 2006). Corylus is planted as an ornamental tree in gardens.

Generally speaking, seven species of Betula occur in Poland. The most frequent are B. pendula Roth (B. verrucosa Ehrh.) and $B$. pubescens Ehrh. The most common species is B. pendula, which occurs throughout the country. In Krakow and its close surroundings, $B$. pendula dominates, while $B$. pubescens occasionally occurs in the Niepołomice Forest and towards the northwestern part of Krakow (Zając and Zając 2006). B. pendula starts flowering 10-12 days earlier than $B$. pubescens (Suszka 1979).

\subsection{Pollen data collection}

The studied taxa were selected on the basis of high allergenicity and the common occurrence in the city and in its close vicinity. Pollen data were collected using the volumetric method in 1991-2012. Two spore traps of the Hirst design (Hirst 1952) were used (Seven Day Recording Volumetric Spore Trap, Burkard Company in 1991-2003 and VPPS 2000, Lanzoni Ltd. in 2004-2010). The samplers were located on the roof of the Collegium Sniadeckiego building (Institute of Botany, Jagiellonian University) in the city centre $20 \mathrm{~m}$ above ground level. Pollen grains were sucked onto a rotating drum covered by transparent (Melinex) tape.

The arrangement of microscopic slides was made according to Jäger et al. (1995). The daily samples were examined using a light microscope at $400 \times$ magnification. Pollen grains were counted along 4 longitudinal transects in 2000-2012, and earlier in 1991-1999, the 12 traverse transects method was employed. Both methods are recommended by the European Aerobiology Society rules of quality control (www.ean.polleninfo.org). The use of both longitudinal and latitudinal (transverse) traverses has been shown to produce comparable results when similar percentages of the slide are examined (Comtois et al. 1999; Carinanos et al. 2000). However, Kapyla and Penttinen (1981) stated that traverses along the length of the slide may give unreliable estimates because of the irregular transverse variation in the deposition of 
particles on the tape. The authors recommended that whole width of the tape should be studied because considerable amounts of particles were also found outside the 14-mm-wide "effectively collecting area" below the orifice (Kapyla and Penttinen 1981). CotosYáñez et al. (2013) also reported that the distribution of the variable number of pollen grains over longitudinal and transversal traverses is not uniform.

Pollen season start was calculated using the pollen grain sum method of 5 grains cumulated since January 1 for Alnus and Corylus, while the pollen grain sum method of 15 grains cumulated since March 1 in case of Betula (about 40 days before the mean season start). The sum cumulative method was recommended by Adams-Groom et al. (2002) and Rodriguez-Rajo et al. (2006).

The seasons were divided into three groups according to the season start day calculated since January 1 and described as follows: for Alnus - early season (E) 12-36th day, moderate season (M) 37-60th day, late season (L) 61st-84th day; for Corylus - early season (E) 11-36th day, moderate season (M) 37th-61st day, late season (L) 62nd85th day; and for Betula - early season (E) 87-95th day, moderate season (M) 96-104th day, late season (L) 105-113th day. Time range from the latest start of the pollen season to the earliest one was divided into three periods, where median of each period was 24.

\subsection{Meteorological data and study idea}

The meteorological data were provided by the Research Station of the Dept. of Climatology, Institute of Geography and Spatial Management, Jagiellonian University $\left(50^{\circ} 04^{\prime} \mathrm{N}, 19^{\circ} 58^{\prime} \mathrm{E}\right.$, h $206^{\circ} \mathrm{m}$ a.s.1.), located in the immediate vicinity of the monitoring site. Minimum, maximum and mean daily temperature as initial data were taken. Mean daily temperature was calculated using the formula: $\left(t_{\max }+t_{\min }+t_{6}+t_{18}\right)$ / 4 ( $t_{6}$ - temperature at 6 a.m. UTC, $t_{18}$ - temperature at 6 p.m. UTC).

Five-day running means of different temperature parameters were calculated because it was found that these variables were the best at describing the relationship between start dates of each studied taxon and thermal conditions. These running means were counted since January 1 to the day calculated as the season start for Alnus and Corylus and since March 5 in case of Betula. Running means including 5 consecutive values of daily mean temperature were named as a 5-day temperature mean. A 5-day mean temperature on January 1 was counted from December 28 to January 1 inclusive, and a 5-day mean temperature on March 5 was counted from March 1 to March 5 inclusive.

The aim of the statistical analysis was to find a model, which would be able to predict a day of the tree pollen season start with a high accuracy. The analysis was based on the changes in temperature before the pollen season. Within a 20 -year aerobiological monitoring, the increase in temperature followed by the temperature decrease just before a season was noted in majority of the studied years (Figs. 1, 2). It was assumed that this relatively short time period of temperature decrease followed by an increase in temperature (described as the "local minimum" from now on) could be used to indicate an approaching pollen season. This "local minimum" will consequently be used analogically to the mathematical terminology (http://mathworld.wolfram.com).

The author's intention was to find such a "local minimum", which could be an optimal indicator. Looking at the Figs. 1 and 2 with 5-day temperature fluctuations, we can see the periods of temperature increase and decrease depending on a given day. The proposed methodology, based on temperature fluctuations just before a season, was named in a working version "hills and dales theory". A day described as the "local minimum" was accepted as a day preceded by at least two days, when the decrease in a 5-day running mean temperature was noted and then followed by at least two days, when the increase in a 5-day running mean temperature was observed. Local minima that occurred less than three days before the season start for each taxon were not included in the analysis.

\subsection{Predictive models}

The nonlinear logistic regression was used to find the probability of the pollen season start up to ten days from the "local minimum" calculated on the basis of 5-day running mean temperature. Whereby the pollen season start is a dichotomous variable that deals with only two possible values: "1" (YES), if the season starts within ten days from the "local minimum", and 

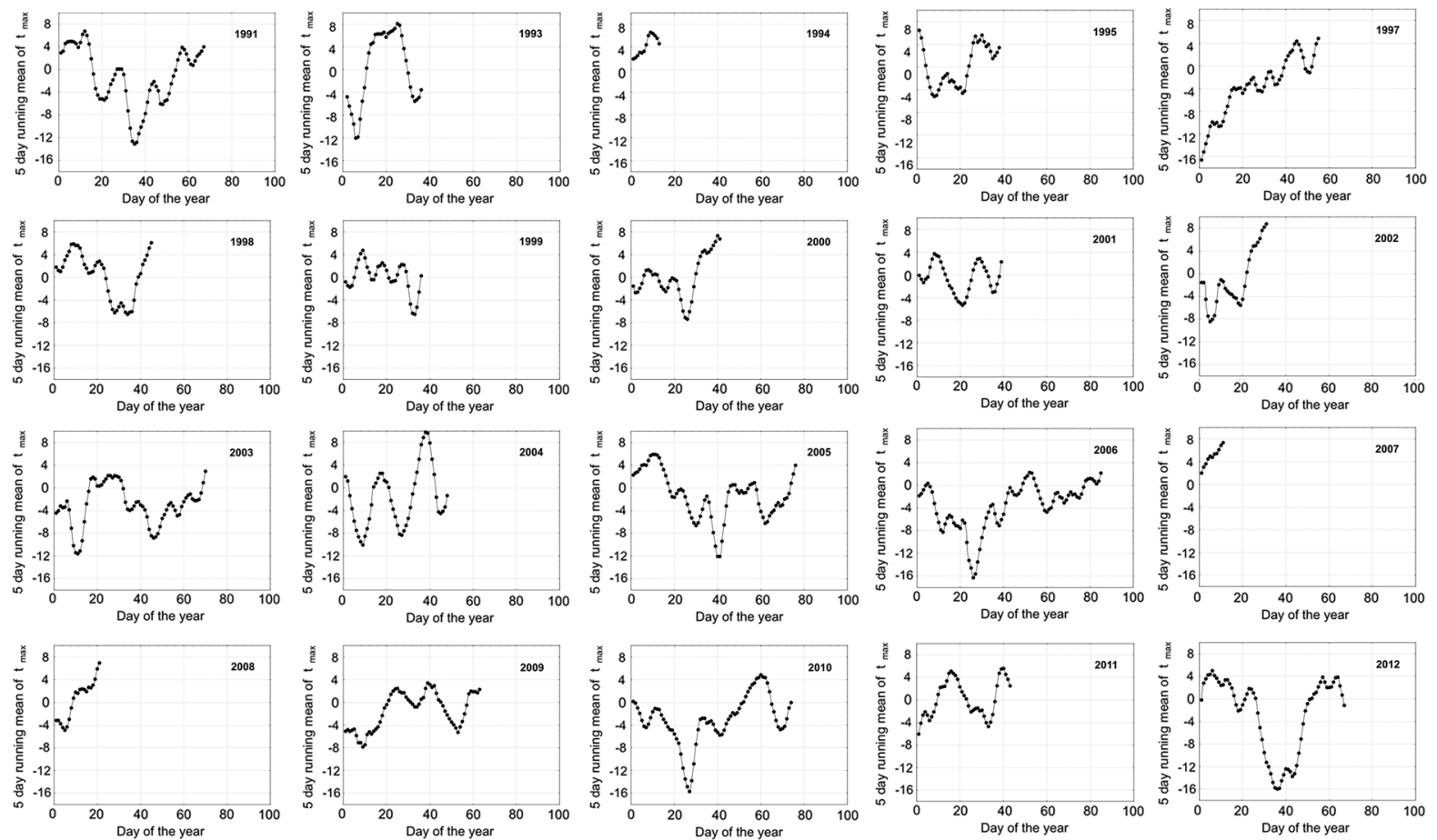

Fig. 1 The scatter plots of seasonal fluctuations of 5-day running mean of maximum temperature (as described in Sect. 2) before the Corylus pollen seasons in Krakow in 1991-2012.
Years of 1992 and 1996 were excluded from the analyses. The cubic spline was used to smooth the curve

Among the constructed models, a 10-day model was selected as the most effective. The models assume that some case will happen when its probability is higher than 0.5 . Presented models were constructed on the basis of pollen and meteorological data obtained in 1991-2010. Then, the models were verified with the data obtained in 2011 and 2012. The values of probability of the Alnus and Corylus pollen season start occurring, calculated using model parameters for critical 5-day running means of maximum temperature ranging from -6 to $+4{ }^{\circ} \mathrm{C}$, were graphically presented. The probability of the Alnus and Corylus pollen season start occurring at a critical temperature of 4 and $-4{ }^{\circ} \mathrm{C}$ was also calculated. In the case of Betula, the probability of pollen season start occurring was presented at critical temperature of 2.4 , 4.4 and $10.5^{\circ} \mathrm{C}$. Temperature values were chosen on the basis of the precise analyses of the thermal situation in the study years. The threshold values were indicated as the lowest or the highest temperature obtained in the analysed "local minimum"; in case of the Betula pollen season, the mean temperature was tested. The aim of this analysis was to test how prediction of the model behaves for threshold values. 

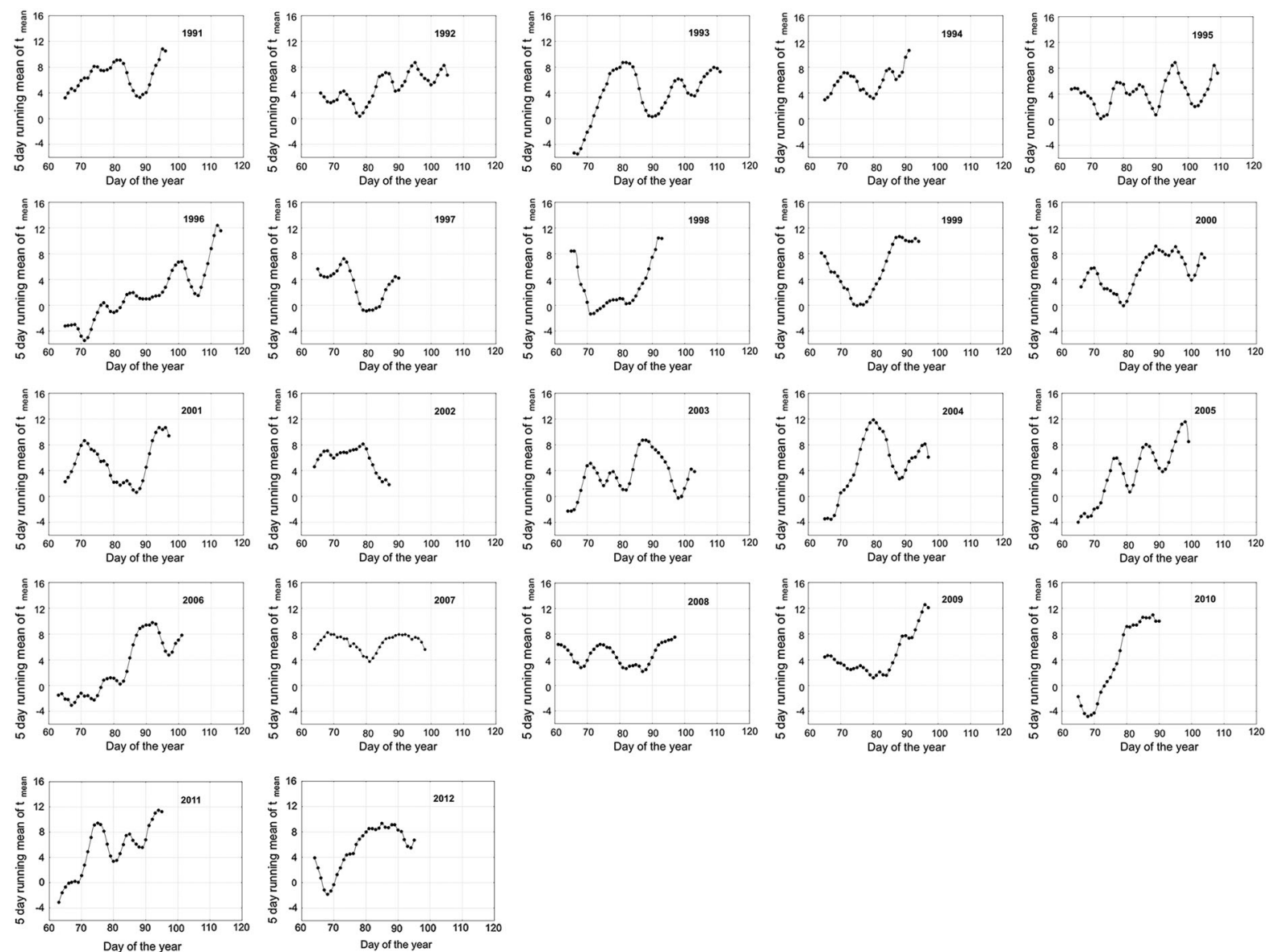

Fig. 2 The scatter plots of seasonal fluctuations of 5-day running mean of maximum temperature (as described in Sect. 2) before the Betula pollen seasons in Krakow in 1991-2012. The cubic spline was used to smooth the curve

Analyses were carried out, using the Statistica program version 9.0.

\section{Results}

\subsection{Tree pollen season start dates}

The pollen seasons of Alnus and Corylus tended to occur at roughly the same time (Table 1). The season starts of both taxa varied strongly from year to year, which makes these characteristics difficult to predict. The seasons started, on average, in the middle of February (46-47th day of the year). In the studied period, no seasons described as early, moderate and late prevailed; the tendency towards earlier or later season start was not found.

In comparison, the Betula pollen seasons started on the 99 th day of the year (on average, \pm 7 days), ranging from April 2 to April 15. The seasons defined as moderate prevailed in the studied period. Betula pollen seasons are more stable in comparison with Alnus and Corylus pollen seasons, which is confirmed by the coefficients of variation (7.3, 46 and $46.2 \%$, respectively).

\subsection{Predictive models}

The logistic regression model for the start of the Alnus pollen season is as follows:

$P(\mathrm{~A})=\frac{e^{-3.588+0.065 * \mathrm{Day}+0.185 * t 5 \text { mean }}}{1+e^{-3.588+0.065 * \mathrm{Day}+0.185 * t 5 \text { mean }}}$

$P(\mathrm{~A})$ - probability of Alnus pollen season start; Day-day of "local minimum"; $t_{5 \text { mean }}-5$-day running mean of maximum temperature; and $e$ - the base of the natural logarithm (about 2.718). 
Table 1 Descriptive statistics of tree pollen season starts in Krakow, in 1991-2010

\begin{tabular}{|c|c|c|c|c|c|c|c|c|c|}
\hline \multirow{2}{*}{$\begin{array}{l}\text { Taxon } \\
\text { Season }\end{array}$} & \multicolumn{3}{|c|}{ Alnus } & \multicolumn{3}{|c|}{ Corylus } & \multicolumn{3}{|c|}{ Betula } \\
\hline & $\Sigma 5^{*}$ & Date & Season type & $\Sigma 5^{*}$ & Date & Season type & $\Sigma 15^{*}$ & Date & Season type \\
\hline 1991 & 67 & $8 / 03$ & $\mathrm{~L}$ & 67 & $8 / 03$ & $\mathrm{~L}$ & 96 & $6 / 04$ & M \\
\hline 1992 & - & - & - & - & - & - & 105 & $14 / 04$ & $\mathrm{~L}$ \\
\hline 1993 & 36 & $4 / 02$ & $\mathrm{E}$ & 36 & $4 / 02$ & $\mathrm{E}$ & 111 & $20 / 04$ & $\mathrm{~L}$ \\
\hline 1994 & 12 & $12 / 01$ & $\mathrm{E}$ & 13 & $13 / 01$ & $\mathrm{E}$ & 91 & $1 / 04$ & $\mathrm{E}$ \\
\hline 1995 & 39 & $8 / 02$ & M & 38 & $7 / 02$ & M & 109 & $25 / 03$ & $\mathrm{~L}$ \\
\hline 1996 & - & - & - & - & - & - & 113 & $23 / 04$ & $\mathrm{~L}$ \\
\hline 1997 & 55 & $24 / 02$ & M & 55 & $24 / 02$ & M & 90 & $25 / 03$ & $\mathrm{E}$ \\
\hline 1998 & 43 & $12 / 02$ & M & 45 & $16 / 02$ & M & 93 & $3 / 04$ & $\mathrm{E}$ \\
\hline 1999 & 35 & $4 / 02$ & $\mathrm{E}$ & 36 & $5 / 02$ & $\mathrm{E}$ & 94 & $4 / 04$ & $\mathrm{E}$ \\
\hline 2000 & 40 & $9 / 02$ & M & 41 & $10 / 02$ & M & 104 & $13 / 04$ & M \\
\hline 2001 & 39 & $8 / 02$ & M & 39 & $8 / 02$ & M & 97 & $7 / 04$ & M \\
\hline 2002 & 25 & $25 / 01$ & $\mathrm{E}$ & 31 & $31 / 01$ & $\mathrm{E}$ & 87 & $28 / 03$ & $\mathrm{E}$ \\
\hline 2003 & 66 & $7 / 03$ & $\mathrm{~L}$ & 70 & $11 / 03$ & $\mathrm{~L}$ & 103 & $13 / 04$ & M \\
\hline 2004 & 51 & $20 / 02$ & M & 48 & $17 / 02$ & M & 97 & $6 / 04$ & M \\
\hline 2005 & 77 & $18 / 03$ & $\mathrm{~L}$ & 76 & $17 / 03$ & $\mathrm{~L}$ & 99 & $8 / 04$ & M \\
\hline 2006 & 84 & $25 / 03$ & $\mathrm{~L}$ & 85 & $26 / 03$ & $\mathrm{~L}$ & 101 & $10 / 04$ & M \\
\hline 2007 & 14 & $14 / 01$ & $\mathrm{E}$ & 11 & $11 / 01$ & $\mathrm{E}$ & 98 & $8 / 04$ & M \\
\hline 2008 & 20 & $20 / 01$ & $\mathrm{E}$ & 21 & $21 / 01$ & $\mathrm{E}$ & 97 & $6 / 04$ & M \\
\hline 2009 & 63 & $4 / 03$ & $\mathrm{~L}$ & 63 & $4 / 03$ & $\mathrm{~L}$ & 97 & $6 / 04$ & M \\
\hline 2010 & 66 & $7 / 03$ & $\mathrm{~L}$ & 74 & $15 / 03$ & $\mathrm{~L}$ & 90 & $31 / 03$ & $\mathrm{E}$ \\
\hline Min & 12 & & & 11 & & & 87.0 & & \\
\hline $\mathrm{Me}$ & 41.5 & & & 43.0 & & & 97.0 & & \\
\hline Max & 84 & & & 85 & & & 113.0 & & \\
\hline $\bar{x}$ & 46.2 & & & 47.2 & & & 98.6 & & \\
\hline SD & 21.3 & & & 21.8 & & & 7.2 & & \\
\hline V\% & 46.0 & & & 46.2 & & & 7.3 & & \\
\hline$-0.95 \% \mathrm{CI}$ & 35.6 & & & 36.3 & & & 89.3 & & \\
\hline$+0.95 \% \mathrm{CI}$ & 56.8 & & & 58.0 & & & 97.7 & & \\
\hline 2011 & 42 & $10 / 02$ & M & 43 & 11/02 & M & 96 & $5 / 04$ & $\mathbf{M}$ \\
\hline 2012 & 66 & $8 / 03$ & $\mathbf{L}$ & 73 & $15 / 03$ & $\mathbf{L}$ & 94 & 4/04 & $\mathbf{E}$ \\
\hline
\end{tabular}

The season starts in 2011 and 2012, as years of model validation are given separately. The Alnus and Corylus season starts in 1992 and 1996 are excluded from the analysis, because of technical problems

* Cumulative pollen sum (day of the year). Symbol of season type: $E$ early; $M$ moderate; and $L$ late season start. Season starts calculated in the years of model validation (in bold)

The logistic regression model for the start of the Corylus pollen season is as follows:

$P(\mathrm{C})=\frac{e^{-4.155+0.074 * \text { Day }+0.215 * t 5 \mathrm{mean}}}{1+e^{-4.155+0.074 * \text { Day }+0.215 * t 5 \mathrm{mean}}}$

$P(\mathrm{C})$-probability of Corylus pollen season start; Day-day of "local minimum"; $t_{5 \text { mean }}-5$-day running mean of maximum temperature; and $e$ - the base of the natural logarithm (about 2.718).
The logistic regression model for the start of the Betula pollen season is as follows:

$P(\mathrm{~B})=\frac{e^{-25.413+0.273 * \mathrm{Day}+0.352 * t 5 \text { mean }}}{1+e^{-25.413+0.273 * \mathrm{Day}+0.352 * t 5 \text { mean }}}$

$P(B)$ - probability of Betula pollen season start; Day-day of "local minimum"; $t_{5 \text { mean }}-5$-day running mean of mean temperature; and $e$ - the base of the natural logarithm (about 2.718). 


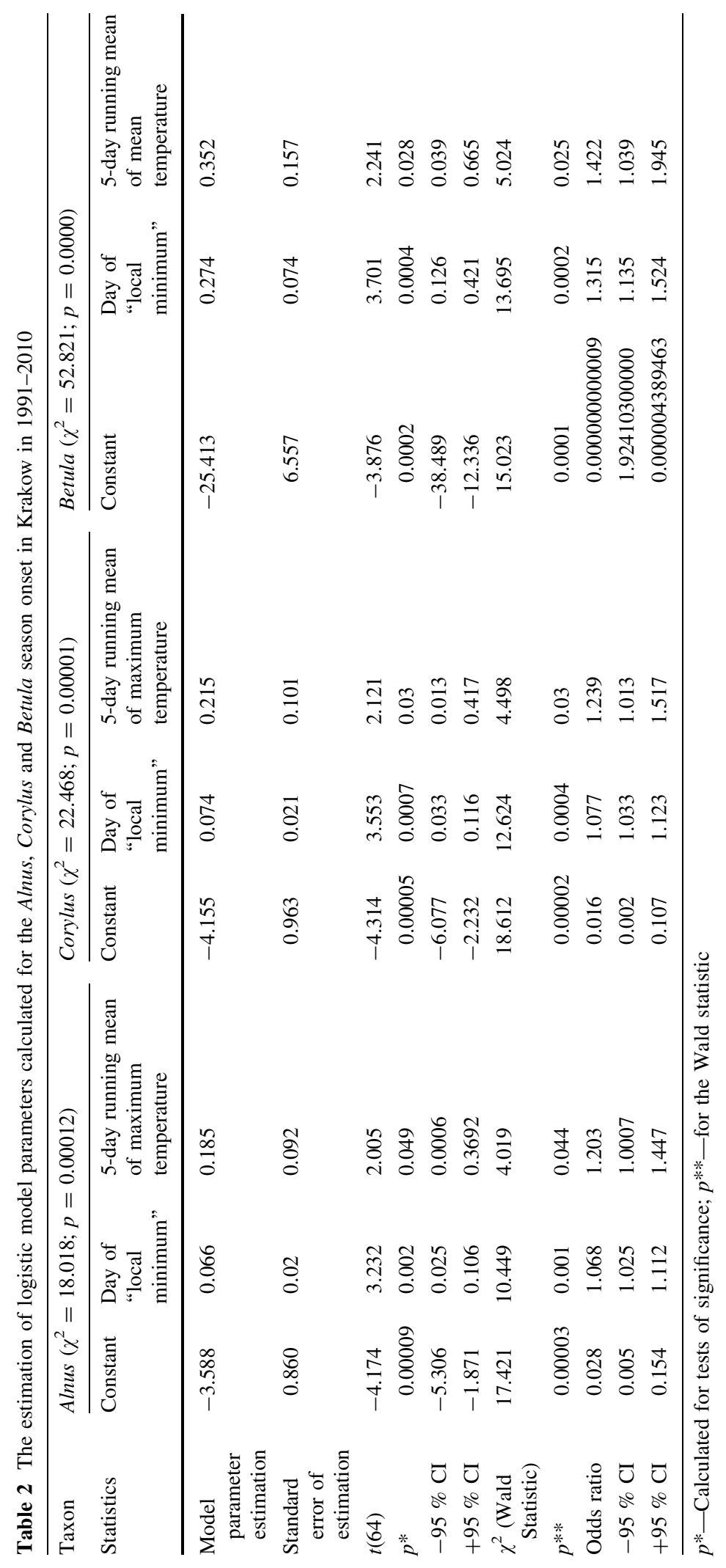


The value of $\chi^{2}$ statistics (goodness of model fit) $\left(\chi^{2}=18.018\right.$ and 22.468, respectively, for Alnus and Corylus; $p<0.05$ ) indicates that the proposed models contribute something new, because they differ from models including the constant only in significant way (Table 2). The estimation of model parameters for the independent variables and also for intercept indicates their statistically significance $(p<0.05)$ for all studied taxa. In models for Alnus and Corylus, the odds ratio accepts positive values for all analysed parameters. On the basis of the OR value, it could be calculated that in 10 days from the "local minimum" the chance of probability of the pollen season occurrence increases twice for Alnus and 2.1 times for Corylus. On the other hand, when the 5-day running mean of maximum temperature increases by $5{ }^{\circ} \mathrm{C}$, the chance of the season start accelerates 2.5 times for Alnus and 2.9 times for Corylus. The value of $\chi^{2}$ statistics obtained for the model constructed for Betula pollen season start dates was higher than for Alnus and Corylus $\left(\chi^{2}=52.821\right)$, and it was also statistically significant $(p<0.05)$ (Table 2$)$. On the basis of the OR value, it could be calculated that in 10 days from the "local minimum" the probability of the pollen season occurring increases 15 times, i.e. 7 times more than in the case of Alnus and Corylus. Moreover, when 5 -day running mean temperatures increase by $5{ }^{\circ} \mathrm{C}$, the chance of the season start accelerates 6 times, which was also higher compared to Alnus and Corylus.

The proposed model for Alnus forecasts "lack of the pollen season" in $94 \%$ of cases, and the season start in $43 \%$ of cases, while the model arranged for Corylus forecasts "lack of the pollen season" in $93 \%$ of cases and the season start in $50 \%$ of cases (Table 3).

The correctness of prediction indicated that the data used for the model arrangement fitted the models well and stressed the high efficacy of model prediction estimated using the pollen data in 1991-2010. Compared to the models proposed for Alnus and Corylus, the model for the Betula accurately predicted that the season would start in $90.41 \%$ of cases (Table 3 ).

Looking at the logistic regression curves of Alnus and Corylus (Fig. 3), it is clear that in case of both taxa, the curves are highly similar. Introducing the different threshold temperature (range from -4 to $6{ }^{\circ} \mathrm{C}$ ), the following relation is observed: when the higher 5-day running mean temperature is achieved, the probability of the season start is increased. In

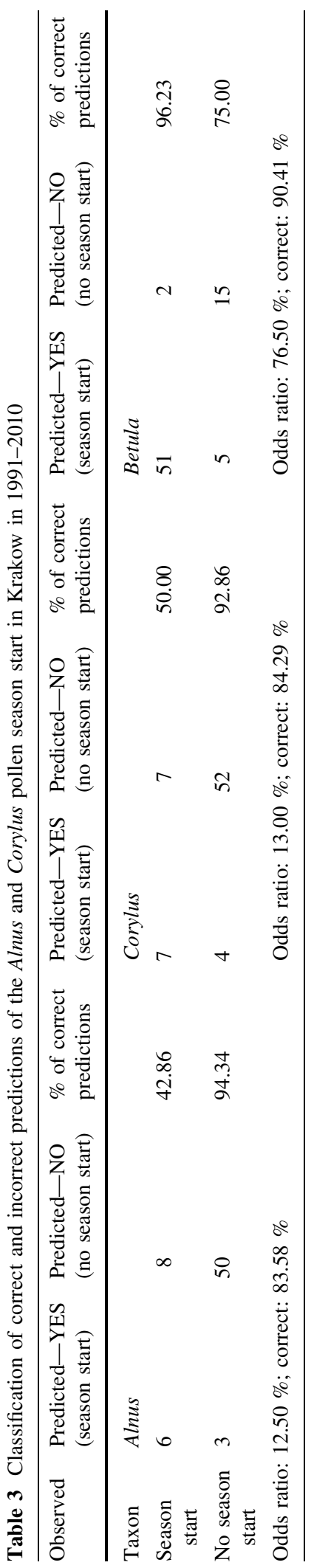


addition, a greater chance of earlier season start dates is expected when higher temperatures are achieved.

At the end of January, the chance of the season start at 5-day running mean temperature around $-4{ }^{\circ} \mathrm{C}$ in comparison with $6{ }^{\circ} \mathrm{C}$ decreases below 0.1 .

When comparing the reaction of Alnus and Corylus at two different threshold temperatures $\left(-4\right.$ and $\left.4{ }^{\circ} \mathrm{C}\right)$, it was observed that the chance of the Alnus pollen season starting is a little higher compared to Corylus pollen seasons at lower temperature $\left(-4{ }^{\circ} \mathrm{C}\right)$ (Fig. 4). When the 5-day running mean temperature is positive $\left(4{ }^{\circ} \mathrm{C}\right)$, the function curves cross about 53rd day of the year. The pollen seasons should start on about 66th day of the year in case of Alnus and on about 68th day in case of Corylus, while at the 5-day running mean temperature $=-4{ }^{\circ} \mathrm{C}$, and on about 44 th day at temperature $4{ }^{\circ} \mathrm{C}$ (for both taxa).

In the case of Betula, the logistic regression curves showed that when higher temperatures are achieved, the probability of the season start increases and a greater chance of an earlier start to the season is expected (Fig. 5). The probability of 0.5 is achieved in the middle of March at a threshold temperature of $10.6{ }^{\circ} \mathrm{C}$ (5-day running mean), but at a threshold temperature of $2{ }^{\circ} \mathrm{C}$, this is achieved at the end of March.

\subsection{Model verification}

The logistic regression models were verified using data from 2011 and 2012 and showed a high efficacy

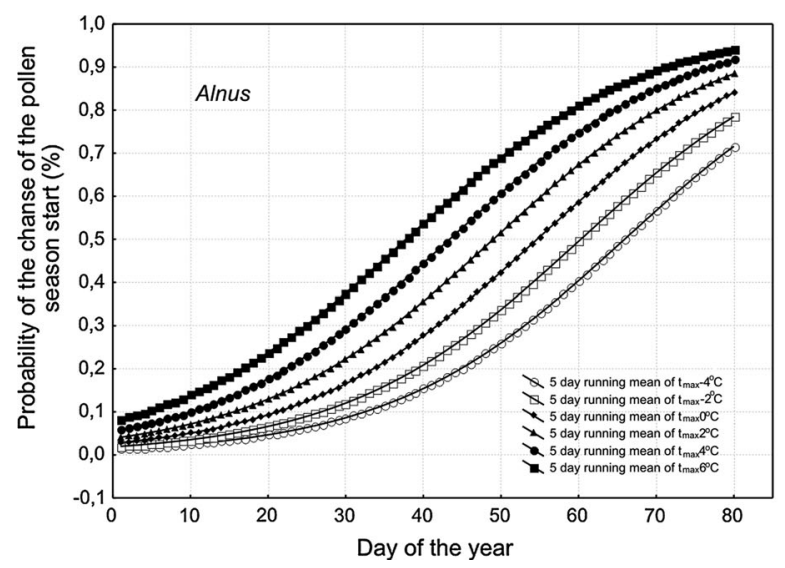

Fig. 3 The graphs of logistic regression function presenting the probability of the pollen season occurrence for Alnus and Corylus at different threshold temperature in Krakow, in of prediction (Table 4). For Alnus and Corylus, three "local minima" were considered in 2011, while in 2012, five "local minima" were considered for Alnus and six for Corylus. In both years, 7 out of 8 cases were predicted correctly, and in the case of Corylus, this was 7 out of 9. In 2012, the chance of pollen season start of both taxa was predicted precisely, but in 2011, the season start dates were not predicted by the proposed model. The Alnus pollen season started on the 42nd day of the year in 2011. The model failed to predict the season start during 9 days after the "local minimum" that occurred on the 33rd day of the year. A similar situation occurred with the Corylus pollen season, which started on the 43rd day of the year in 2011. In 2012, the Alnus pollen season started on the 66th day of the year, 6 days after the "local minimum", the Corylus pollen seasons started later, on the 73rd day, as the model predicted. In the case of the Corylus pollen season start date, the model correctly predicted the chance of the season occurring after two "local minima" (60 and 68th day of the year), both appeared within 10 days of the observed season start".

In the case of Betula pollen seasons, two "local minima" in 2011 and four "local minima" in 2012 were considered for model verification (Table 4). In all the analysed cases, the model predictions achieved $100 \%$ accuracy. In 2011, the chance of the season start was predicted after the second "local minimum", and the Betula pollen season started 6 days after this. In 2012, an evident decrease in 5-day running mean temperatures occurred on the day immediately before

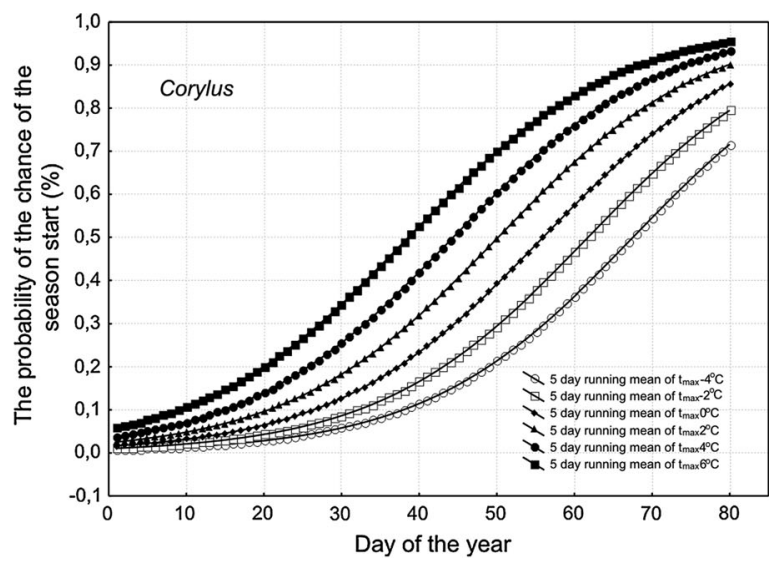

1991-2010. In both cases, 5-day running mean of maximum temperature was calculated (as described in Sect. 2) 


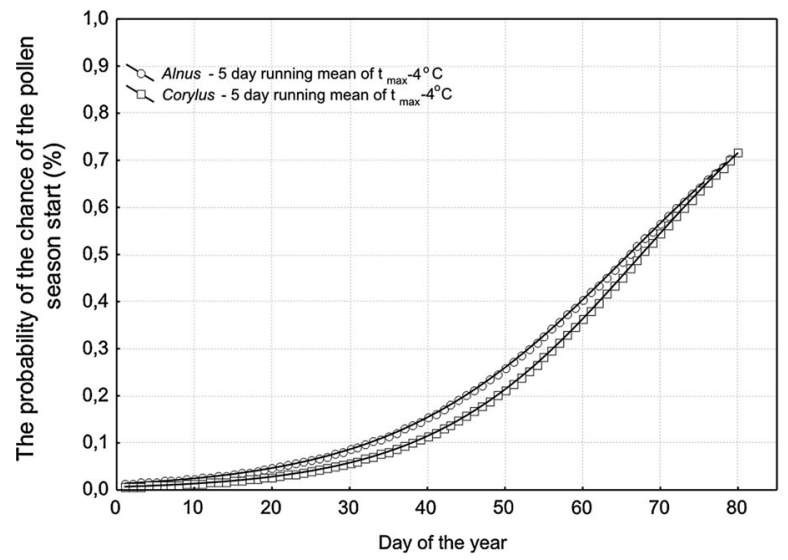

Fig. 4 The graphs of logistic regression function presenting the probability of the pollen season occurrence for Alnus and Corylus at two threshold temperatures $\left(-4\right.$ and $\left.4{ }^{\circ} \mathrm{C}\right)$ in

an observed season start. Two "local minima" (86th and 93rd day of the year) were correctly considered as potential days of season start, which was similar to the prediction for Corylus pollen season start dates.

\section{Discussion}

In temperate climates, weather conditions occurring at the beginning of the year strongly influence the phenology of trees. These conditions are responsible for plant growth and flowering, but the high variability makes forecasting difficult. For this reason, thermal conditions just before a season should be considered when modelling, because it is almost impossible to make long-range weather predictions for the period January to March, and conditions at this time directly influence the season start.

According to Scamoni (1956), the onset of the Alnus pollen season is related to temperatures in the 10 days immediately before the start of a season and pollination is related to warm and dry weather. In the case of Betula, the influence of temperatures during this 10-day period before the start of the pollen season was identified by Adams-Groom et al. (2002). This 10-day period is one of the reasons for paying special attention to temperature fluctuations in spring.

In the present study, logistic regression models were built using temperature fluctuations at the beginning of a year. The models included two independent variables: the day of "local minimum"

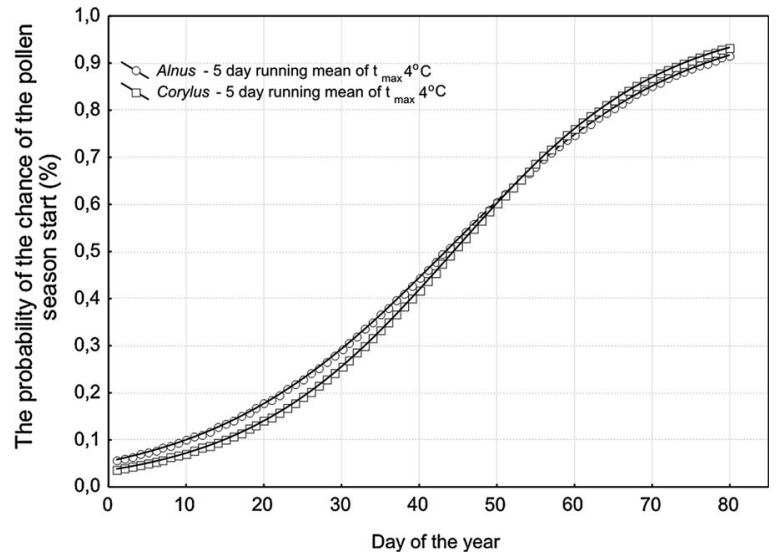

Krakow, in 1991-2010. In both cases, the 5-day running mean of maximum temperature was calculated (as described in Sect. 2)

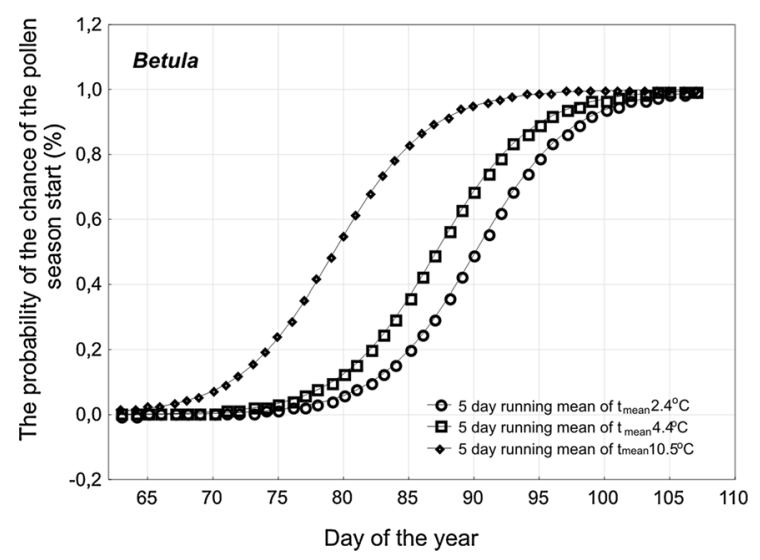

Fig. 5 The graph of logistic regression function presenting the probability of the pollen season occurrence for Betula at different threshold temperature in Krakow, in 1991-2010. The 5-day mean temperature as 5-day running mean of mean temperature was calculated (as described in Sect. 2)

and the value of temperature in the days of "local minimum". This statistical method was also used by Ribeiro et al. (2007) to define the main pollen season of several taxa. The authors concluded that the fit between the values of the accumulated sum of daily airborne pollen concentrations and the curve calculated using this statistical method was almost perfect.

Heat accumulation after the time of temperature decrease was considered by the author on a "microscale" because of the short period between the start of thermal warming in the spring and the onset of pollen seasons. Significant relationships were found between 


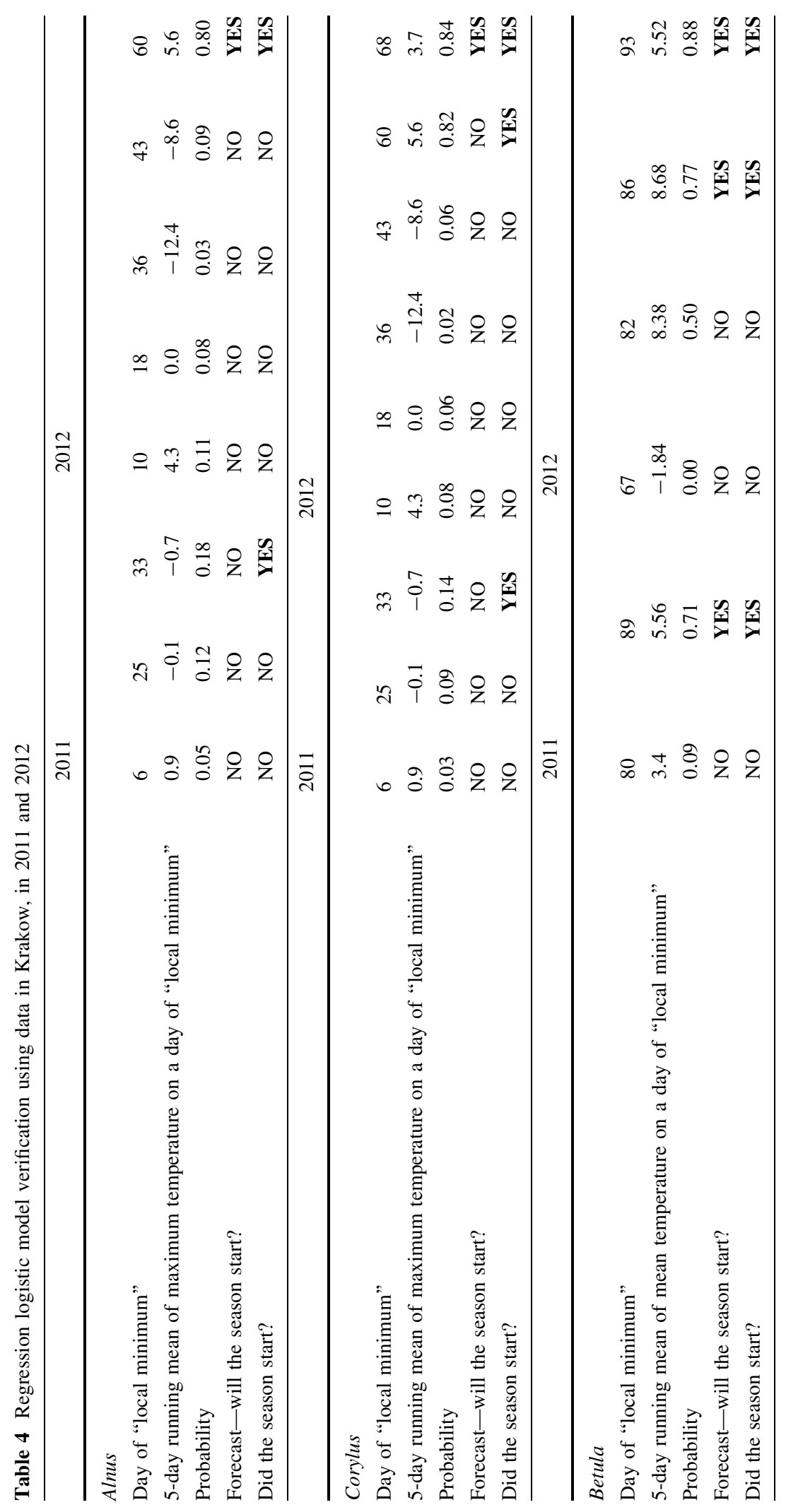


start dates of Alnus and Corylus pollen seasons and fluctuating temperatures before the season (5-day running mean of maximum temperatures). GonzálezParrado et al. (2006) calculated heat requirements at $t_{\max }$ with a threshold temperature of $0{ }^{\circ} \mathrm{C}$. The multiple regression models predicting the Alnus pollen season start and including chilling accumulation and heat requirements as independent variables achieved $95 \%$ of accuracy. Piotrowska and Kaszewski (2009) reported that the onset of the Corylus pollen season is related to the number of days when $t_{\text {mean }}<0{ }^{\circ} \mathrm{C}$ and cumulated $t_{\text {mean }}$ in 5-days before a season. Frenguelli et al. (1991) showed that in the Mediterranean area, Alnus pollen season start dates depended on $t_{\text {mean }}$ in the three decades of days before a season. Another study about Corylus pollen season start dates in Italy (Frenguelli et al. 1992) reported that thermal conditions in the 10-day period before a season have an impact on the season start provided that $t_{\text {mean }}>4.5^{\circ} \mathrm{C}$. If mean temperatures do not achieve this threshold value during the period 10 days before the season start, then the season start could be delayed by up to 30-35 days. Similarly, in the present paper, it was documented that at increasing 5-day running mean of maximum temperature, the chance of the season start in case of Alnus and Corylus increases several times. The response to temperature fluctuations of Corylus seems to be a little bit faster.

Start dates of Betula pollen seasons in Krakow were found to be more stable than start dates of Alnus and Corylus pollen seasons in the city. This phenomenon could be explained by the more stable thermal conditions in the months when Betula pollen is usually recorded (March, April). As reported by Sarvas (1967), B. pendula pollination starts in Poland, Germany, the Czech Republic, Slovakia and southern Finland when $4.1-5.4 \%$ of the mean annual sum of temperature, calculated above the threshold value of $5{ }^{\circ} \mathrm{C}$, is achieved. The author also pointed out that the thermal conditions during the 30-day period before a pollen season determine the beginning and intensity of pollination. The present paper demonstrates that more or less intensive temperature fluctuations occur during the 30 days before a season. The analysis of the plant response in relation to these fluctuations seems to be more objective.

Norris-Hill (1998) presented the highly effective multiple regression models $(R=0.996)$ predicting the Betula pollen season onset using $t_{\text {mean }}$ in February, while Laadi (2001) showed an evident impact of $t_{\max }$ in a 10-day period in the third decade of February and $t_{\min }$ at the end of November. In other studies performed in England, Emberlin et al. (1993) found cumulated $t_{\text {mean }}$ in March as the most important indicator of the Betula pollen season start, but the proposed models (multiple regression) achieved only $54.5 \%$ of accuracy. Moreover, if $t_{\text {mean }}$ in February and March was considered, the models' efficacy increased up to $61.8 \%$. The thermal conditions in February were also considered by Bringfelt et al. (1982), both $t_{\text {mean }}$ and $t_{\max }$, while Spieksma et al. (1995) indicated that the air temperature during the preceding 4 decades of days before the Betula pollen season start is of decisive importance. One of a few examples of dynamic models based on the GDH calculation was presented by Andersen (1991). This model predicted the season start with a 3-5 day precision.

\section{Conclusions}

1. The temperature decrease followed by the temperature increase (named as "local minimum") was found as an indicator of a coming pollen season of Alnus, Corylus and Betula. Basing on this observation, 5-day running means of maximum or mean daily temperature (depending on a studied taxon) were included into the logistic regression models predicting the probability of pollen season start.

2. The estimation of model parameters indicated their statistical significance for all studied taxa; the odds ratio was higher in models for Betula, comparing to Alnus and Corylus.

3. The correctness of prediction indicated that the data used for the model arrangement fitted the models well and stressed the high efficacy of model prediction estimated using the pollen data in 1991-2010. Compared to the models proposed for Alnus and Corylus, the model for the Betula predicted the season start with the highest accuracy.

4. The model verification using data from 2011 to 2012 confirmed a high efficacy of prediction. In case of Alnus and Corylus, the chance of pollen season start of both taxa was predicted more precisely in 2012, while in case of Betula, the model predictions achieved $100 \%$ accuracy in both years. 
5. The proposed models seem to be a good tool for aerobiological and medical purposes, expanding the knowledge of the early-pollinating tree pollination and pollen seasons.

Acknowledgments The study was supported by the statutory project of the Ministry of Science and Higher Education No. K/ZDS/002432 (2011-2013). The author would like to thank the management of the Department of Climatology, Jagiellonian University, for providing with the meteorological data and M.Sc. Katarzyna Leśkiewicz from the Institute of Information and Library Science for her cooperation in statistical analysis. Many thanks to the management of the Institute of Botany Jagiellonian University for the permission to locate the volumetric sampler.

Open Access This article is distributed under the terms of the Creative Commons Attribution License which permits any use, distribution, and reproduction in any medium, provided the original author(s) and the source are credited.

\section{References}

Raport o stanie miasta./Report on city conditions 2011. (2012). Urząd Miasta Wydział Strategii i Rozwoju Miasta. http:// www.bip.krakow.pl/zalaczniki/okumenty/n/97139/karta.

Adams-Groom, B., Emberlin, J., Corden, J., Millington, W., \& Mullins, J. (2002). Predicting the start of the Betula pollen season at London, Derby and Cardiff, United Kingdom, using a multiple regression model, based on data from 1987 to 1997. Aerobiologia, 18, 117-123.

Andersen, T. B. (1991). A model to predict the beginning of the pollen season. Grana, 30, 269-275.

APGII. (2003). An update of the Angiosperm Phylogeny Group classification for the orders and families of flowering plants: APG II. Botanical Journal of the Linnean Society, 141(4), 399-436.

APGIII. (2009). An update of the Angiosperm Phylogeny Group classification for the orders and families of flowering plants: APG III. Botanical Journal of the Linnean Society, 161, 105-121.

Bringfelt, B., Engström, I., \& Nilsson, S. (1982). An evaluation of some models to predict airborne pollen concentration from meteorological conditions in Stockholm, Sweden. Grana, 21, 59-64.

Burbach, G. J., Heinzerling, L. M., Edenharter, G., Bachert, C., Bindslev-Jensen, C., Bonini, S., et al. (2009). GA2LEN skin test study II: Clinical relevance of inhalant allergen sensitizations in Europe. Allergy, 64(10), 1507-1515.

Burr, M. L. (1999). Grass pollen: Trends and predictions. Clinical and Experimental Allergy, 29, 735-738.

Carinanos, P., Emberlin, J., Galán, C., \& Domingues-Vilches, E. (2000). Comparison of two pollen counting methods of slides from a Hirst type volumetric trap. Aerobiologia, 16, 339-346.

Chappard, C., Bonnevial, J., Colson, M., Mathern, G., \& Emonot, A. (2004). Forecast of pollination dates and relation to onset of allergic pathology. Aerobiologia, 20, 35-42.

Chuine, I., \& Belmonte, J. (2004). Improving prophylaxis for pollen allergies: predicting the time course of the pollen load of the atmosphere of major allergenic plants in France and Spain. Grana, 43, 65-80.

Clot, B. (2001). Airborne birch pollen in Neuchatel (Switzerland), onset, peak and daily patterns. Aerobiologia, 17, 25-29.

Comtois, P., Alcazar, P., \& Neron, D. (1999). Pollen counts statistics and its relevance to precision. Aerobiologia, 15, 19-28.

Corden, J., Millington, W., Bailey, J., Brookers, M., Caulton, E., Emberlin, J., et al. (2000). UK regional variations in Betula pollen. Aerobiologia, 16, 227-323.

Cotos-Yáñez, C. R., Rodríguez-Rajo, F. J., Pérez-González, A., Aira, M. J., \& Jato, V. (2013). Quality control in aerobiology: Comparison different slide reading methods. Aerobiologia, 29, 1-11. doi:10.1007/s10453-012-9263-1.

Dąbrowska-Zapart, K. (2008). The influence of meteorological factors on the hazel (Corylus L.) pollen concentration in Sosnowiec in the years 1997-2007. Acta Agrobotanica, 61(2), 49-56.

Dahl, A., Galán, C., Hajkova, L., Pauling, A., Sikoparija, B., Smith, M., et al. (2013). The onset, course and intensity of the pollen season. In M. Sofiev \& K-Ch. Bergmann (Eds.), Allergenic pollen. A review of the production, release, distribution and health impacts (pp. 29-70). Dordrecht: Springer.

Emberlin, J., Savage, M., \& Woodman, R. (1993). Annual variations in Betula pollen seasons in London, 1961-1990. Grana, 32, 359-363.

Emberlin, J., Smith, M., Close, R., \& Adams-Groom, B. (2007). Changes in the seasons of the early flowering trees Alnus spp. and Corylus spp. in Worcester, United Kingdom, 1996-2005. International Journal of Biometeorology, 51, 181-191.

Frenguelli, G., \& Bricchi, E. (1998). The use of the phenolclimatic model for forecasting the pollination of some arboreal taxa. Aerobiologia, 14, 39-44.

Frenguelli, G., Bricchi, E., Romano, B., Mincigrucci, G., Ferranti, G., \& Antognozzi, E. (1992). The role of air temperature in determining dormancy release and flowering of Corylus avellana L. Aerobiologia, 8, 415-418.

Frenguelli, G., Spieksma, F. T., Bricchi, E., Romano, B., Mincigrucci, G., Nikkels, A. H., et al. (1991). The influence of air temperature on the starting dates of the pollen season of Alnus and Populus. Grana, 30, 196-200.

González-Parrado, Z., Fuertes-Rodríguez, C. R., Vega-Maray, A. M., Valencia-Barrera, R. M., Rodríguez-Rajo, F. J., \& Fernández-González, D. (2006). Chilling and heat requirements for the prediction of the beginning of the pollen season of Alnus glutinosa (L.) Gaertner in Ponteferrada (León, Spain). Aerobiologia, 22, 47-53.

Hirst, J. M. (1952). An automatic spore trap. Annals of Applied Biology, 39, 257-265.

Jäger, S., Mandrioli, P., Spieksma, F., Emberlin, J., Hjelmroos, M., Rantio-Lehtimäki, A., et al. (1995). News. Aerobiologia, 11, 69-70.

Jato, V., Frenguelli, G., Rodriguez, F. J., \& Aira, M. J. (2000). Temperature requirements of Alnus pollen in Spain and Italy (1994-1998). Grana, 39, 240-245. 
Kapyla, M., \& Penttinen, A. (1981). An evaluation of the microscopical counting methods of the tape in Hirst-Burkard pollen and spore trap. Grana, 20, 131-141.

Laadi, K. (2001). Regional variations in the pollen season of Betula in Burgundy: Two models for predicting the start of the pollination. Aerobiologia, 17, 247-254.

Linkosalo, T., Ranta, H., Oksanen, A., Siljamo, P., Luomajoki, A., Kukkonen, J., et al. (2010). A double-threshold temperature sum model for predicting the flowering duration and relative intensity of Betula pendula and B. pubescens. Agriculture and Forest Meteorology, 150, 1579-1784.

Myszkowska, D. (2013). Prediction of the birch pollen season characteristics in Krakow, Poland using an 18-year data series. Aerobiologia, 29, 31-44.

Myszkowska, D., Dyga, W., \& Piotrowicz, K. (2006). Sezony pylenia olszy i leszczyny w Krakowie w roku 2005 na tle ostatnich 8 lat./Pollen seasons of Alnus and Corylus in Kracow in 1997-2005. Alergologia. Immunologia, 3(1-2), 34-35.

Norris-Hill, J. (1995). The modelling of daily Poaceae pollen concentration. Grana, 34, 182-188.

Norris-Hill, J. (1998). A method to forecast the start of the Betula, Platanus and Quercus pollen seasons in North London. Aerobiologia, 14, 165-170.

Piotrowicz, K. (2007). Temperatura powietrza./Temperature of the air. In D. Matuszko (Ed.), Klimat Krakowa w XX wieku (pp. 99-112). Kraków: Instytut Geografii i Gospodarki Przestrzennej Uniwersytetu Jagiellońskiego.

Piotrowicz, K., \& Myszkowska, D. (2006). Początek sezonów pyłkowych leszczyny na tle zmienności klimatu Krakowa./The start of the hazel pollen seasons on the background of climatic changes in Krakow. Alergologia. Immunologia, 3, 86-89.

Piotrowska, K., \& Kaszewski, B. M. (2009). The influence of meteorological conditions on the start of the hazel (Corylus L.) pollen season in Lublin, 2001-2009. Acta Agrobotanica, 62, 59-66.

Puc, M., \& Kasprzyk, I. (2013). The patterns of Corylus and Alnus pollen seasons and pollination periods in two Polish cities located in different climatic regions. Aerobiologia,. doi:10.1007/s10543-013-9299-x.

Ribeiro, H., Cunha, M., \& Abreu, I. (2007). Definition of main pollen season using a logistic model. Annals of Agriculture and Environmental Medicine, 14, 259-264.
Rodriguez-Rajo, F. J., Dopazo, A., \& Jato, V. (2004). Environmental factors affecting the start of pollen season and concentrations of airborne Alnus pollen in two localities of Galicia (NW Spain). Annals of Agriculture and Environmental Medicine, 11, 35-44.

Rodriguez-Rajo, F. J., Valencia-Barrera, R. M., Vega-Maray, A. M., Suarez, F. J., Fernando-Gonzales, D., \& Jato, V. (2006). Prediction of airborne Alnus pollen concentration by using Arima models. Annals of Agriculture and Environmental Medicine, 13, 25-32.

Samoliński, B., Sybilski, A. J., Raciborski, F., Tomaszewska, A., Samel-Kowalik, P., Walkiewicz, A., et al. (2009). Prevalence of rhinitis in Polish population according to the ECAP (Epidemiology of Allergic Disorders in Poland) study. Otolaryngologia Polska, 63, 324-330.

Sarvas, R. (1967). The annual period of development of forest trees. Proceedings of the Finnish Academy of Science and Letters, 1965, 211-231.

Scamoni, A. (1956). Beobachtungen über den Pollenflug der Waldbäume in Eberswalde. Z. Forstgenetik, 4(4-5), 113-122.

Seneta, W., \& Dolatowski, J. (2007). Dendrologia. (Dendrology). Warszawa: Państwowe Wydawnictwo Naukowe PWN.

Sofiev, M., Bousquet, J., Linkosalo, T., Ranta, H., Rantio-Lehtimaki, A., Siljamo, P., et al. (2009). Pollen, allergies and adaptation. In K. L. Ebi, et al. (Eds.), Biometeorology for adaptation to climate variability and change (pp. 75-106). Berlin: Springer.

Spieksma, F Th M, Emberlin, J., Hjelmroos, M., Jäger, S., \& Leuscher, R. M. (1995). Atmospheric birch (Betula) pollen in Europe: Trends and fluctuations in annual quantities and the starting dates of the seasons. Grana, 34, 51-57.

Suszka, B. (1979). Rozmnażanie generatywne./Generative reproduction. In S. Białobok (Ed.), Brzozy-Betula L. Nasze drzewa leśne (pp. 200-264). Warszawa, Poznań: Państwowe Wydawnictwo Naukowe PWN.

Woś, A. (1999). Klimat Polski. (Climate of Poland). Warszawa: Państwowe Wydawnictwo Naukowe PWN.

Zając, A., \& Zając, M. (2006). Flora Cracoviensis Secunda (Atlas). Kraków: Laboratory of Computer Chorology, Institute of Botany Jagiellonian University and Fundation of Jagiellonian University. 